\title{
COHESION STRENGHT TEST OF SELECTED COMMERCIAL HVOF COATINGS
}

\author{
1Jakub ANTOŠ, 2 Josef DULIŠKOVIČ, ${ }^{3}$ Petra ŠULCOVÁ, ${ }^{4}$ Kateřina LENCOVÁ \\ 1,2,3 ZCU - University of West Bohemia, Pilsen, Czech Republic, EU, \\ 19antos@vzuplzen.cz, ${ }^{2}$ duliskovic@vzuplzen.cz, ${ }^{3}$ sulcova@vzuplzen.cz \\ 4VZUP - Research and Testing Institute Pilsen, Pilsen, Czech Republic, EU, @lencova@vzuplzen.cz
}

https://doi.org/10.37904/metal.2021.4206

\begin{abstract}
High velocity oxy-fuel spraying (HVOF) being one of thermal spraying techniques, is deployed in many commercial applications mostly for very hard wear and/or corrosion resistant coatings. Supersonic speed of the spraying jet combined with temperatures around $5500 \mathrm{~K}$ is utilized to spray most metals, metallic alloys, cermets and superalloys [1-3]. Typical HVOF coatings are compact, dense, with very low porosity, low to moderate oxidation level and high bonding strength to substrate [1]. Cermets and superalloys are standardly commercially applied HVOF materials, demanded for superb wear resistance, high hardness, abrasion and erosion resistance and overall great performance in high stress and/or high temperature environments. Proper testing methods are required to evaluate quality of deposited coatings and consequently choose coating with optimized properties for demanded application. There are many testing methods standardly and widely used for evaluating properties of thermally sprayed coatings - such as superficial indentation, micro and nanoindentation on cross section of the coating, tensile adhesion strength test, many tribological tests, etc. [1]. This article concerns modified TCT (tubular coating tensile test) for testing cohesion strength of the coatings with the use of common tensile test equipment. In this paper, specimen assembly, coating deposition, testing procedure and calculation of results is described. Cohesion strengths of five HVOF commercial coatings: Stellite 6, Hastelloy C 276, $\mathrm{Cr}_{3} \mathrm{C}_{2}-25 \mathrm{NiCr}$, WC $10 \mathrm{Co} 4 \mathrm{Cr}$ and $\mathrm{NiCrFeSiBC}$ are evaluated.
\end{abstract}

Keywords: Thermal spraying, HVOF, cohesion strength, thermal spray coating testing, cermet coating, tubular coating tensile test, TCT test

\section{INTRODUCTION}

HVOF (high velocity oxyfuel spray) thermal spray coatings are mostly used to increase parts performance in severe wear, abrasive or erosive conditions and to improve thermal and/or corrosive resistance. Carbides such as $\mathrm{WC}$ or $\mathrm{Cr}_{3} \mathrm{C}_{2}$ in metallic matrix (e.g. Co, $\mathrm{CoCr}$, NiCr) are most common commercial wear resistant coatings [1]. On part where not only wear, but also corrosion and high temperature resistance is required, Stellite or some other metallic alloy coatings (such as $\mathrm{NiCrSiB}$ ) are employed [2,4]. All those materials features dense lamellar structure with very low porosity and high substrate-coating adhesion [1,2,4].

Because of generally superb adhesion strength between HVOF coatings and most substrate materials, full delamination on the interface between coating and substrate is quite rare as primary failure mechanism under most industrial operating conditions. Adhesion strength pull-off tests are commonly used to evaluate adhesive properties of the thermally sprayed coatings, HVOF coating included. In this pull-off test, a glue of known adhesion strength is utilized to stick together coated sample with counterpart to produce specimen for pull-off test. However, most HVOF coatings-substrate systems, when properly sprayed, display higher adhesion strength on the substrate-coating interface, than adhesive strength of the glue-coating interface. Therefore results of such tests can only prove, that the real adhesive strength of the coating is above the adhesion limits of the glue used for the test. On the other hand, cohesion strength of the coating might be evaluated in pull-off 
test only in case, when it is both lower than adhesion in substrate-coating and coating-glue interfaces. In this case, the failure mechanism during pull-off test is inside the coating - cohesive strength of the splats are exceeded in tensile state and the coating integrity fails

In order to evaluate cohesion integrity of coatings, where pull-off test results are not sufficient, special testing procedures called TCT tests (tubular coating tensile test) are utilized. Some examples of this testing procedure can be found in literature, e.g. $[5,6,7]$. The preparation of test specimens, testing, evaluation of test results and cohesion strength of some commercial HVOF coatings are presented in this paper.

\section{COHESION STRENGHT TEST}

\subsection{Specimens preparation and coating deposition}

Testing specimen compose of two cylinders with same outer diameter and with coaxial inner mounting. Those two cylinders can be fitted together tightly to form a single cylindrical surface. Frontal surfaces of each cylinder as well as the coaxial mounting and outer diameters have to be machined with precision and within strict tolerances to perfectly match each other. Figure 1 a) shows specimens, both assembled and disassembled with visible dividing plane, and Figure $\mathbf{1}$ b) shows both halves of testing specimen separated with visible coaxial mounting.

After assembling both halves of each specimen with screw connection trough the center hole, surface was degreased, grid blasted and coating was deposited. Precise diameter measurement took place before blasting and after spraying - both at ambient temperatures. Coating was sprayed on the outer cylindrical plane in order to connect both halves of the specimen assembly with the coating. Surface temperatures were measured during spraying process with laser pyrometer calibrated to each material specific emissivity (emissivity values were measured for ambient temperature). Same spraying pattern with same number of spraying passes were utilized to spray all materials. Surface temperature during spraying did not pass $110^{\circ} \mathrm{C}$. After the spraying was finished, screw connection was removed and both halves sticked together only with the coating. In this state, specimens are ready to undergo tensile test according to ISO 6892-1 [8].

For every coating material, four specimen assemblies were prepared. Specimen material was mild steel.

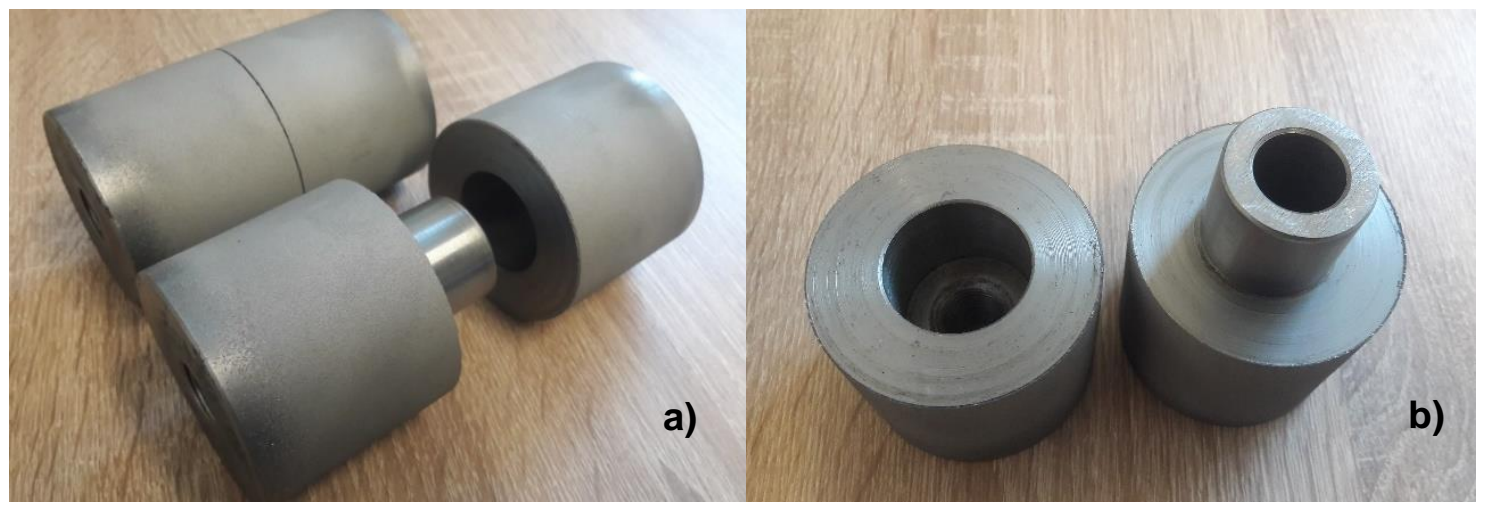

Figure 1 a) two coated specimen after cohesion failure of the coating as a result of tensile test, b) separated halves of a tested specimen

\subsection{Testing procedure}

During tensile test, growing axial force is applied on the coated specimen. Since both halves of specimen are connected together only by the coating, tensile stress develops in the coating cross section on this interface. After tensile stress reaches the cohesion strength limit, the coating failure occurs on the interface. Force at breaking point is a result required for further calculations. 


\subsection{Calculation of results}

With known diameters of the specimen before and after spraying, area of the coating cross section (annulus) can be calculated as shown in equation (1). This anulus is the area where tensile stress is induced during tensile test. Force at the rupture point of the coating is proportional to the ultimate tensile strength, which is calculated according to equation (2). Ultimate tensile strength calculated as explained above is equal to the cohesion strength of the coating, since the fracture mechanics of the coating after this test is always coating cohesion failure.

For the means of calculation of the results, it was presumed that tensile force applied in the axis of specimen is perfectly coaxial with coating annulus, thus inducing uniform tensile stress in the coating cross section. However, in reality there are always manufacturing and assembling inaccuracies, leading to a possible axial misalignment of both halves of the tested specimens. For this reason, it can be assumed that besides to a pure tension, other stresses types can emerge during tensile test, such as shear stress. However, in the calculation of the results, simple tensile stress was considered. Therefor the real cohesion strength can be slightly higher than the strength calculated from this test due to the possible combined stresses effect emerging during tensile test.

$S_{\text {coating }}=\frac{\pi D^{2}}{4}-\frac{\pi d^{2}}{4}=\frac{\pi}{4}\left(D^{2}-d^{2}\right)$

$R_{m}=\frac{F_{m}}{S_{\text {coating }}}$

where:

$$
\begin{aligned}
& \mathrm{D} \text { - diameter after spraying }(\mathrm{mm}) \\
& \mathrm{d} \text { - diameter before spraying }(\mathrm{mm}) \\
& \mathrm{S}_{\text {coating }} \text { - area of the coating cross section }\left(\mathrm{mm}^{2}\right) \\
& R_{m} \text { - ultimate tensile strength }(\mathrm{MPa}) \\
& F_{m}-\text { force at rupture }(\mathrm{N})
\end{aligned}
$$

\subsection{Tested materials specifications}

Five commercial HVOF powders were chosen to underwent this test - see Table 1. All of selected powders are used to produce commercial coatings in VZÚ Plzeň s.r.o. with the utilization of optimized spraying parameters. As spraying equipment, JP-5220 HVOF gun with FST HV-50 control unit and FST-20C/FT dual powder feeder was utilized.

Table 1 Commercial powders used in cohesion strength test

\begin{tabular}{|c|c|c|c|}
\hline $\begin{array}{c}\text { Commercial } \\
\text { designation }\end{array}$ & Chemical composition & $\begin{array}{c}\text { Material } \\
\text { equivalent }\end{array}$ & Manufacturer \\
\hline Woka 3652 & WC $10 \mathrm{Co} 4 \mathrm{Cr}$ & & Oerlikon Metco \\
\hline M-484.33 & $\mathrm{Co} 28.5 \mathrm{Cr} 4.5 \mathrm{~W} 1 \mathrm{C} 1 \mathrm{Si}$ & Stellite 6 & Flame Spray Technologies \\
\hline M-771.33 & $\mathrm{Ni} 16 \mathrm{Cr} 4 \mathrm{Fe} 4.25 \mathrm{Si} 3 \mathrm{~B} 0.7 \mathrm{C}$ & & Flame Spray Technologies \\
\hline Amperit 588.074 & $\mathrm{Cr}_{3} \mathrm{C}_{2} 25 \mathrm{NiCr}$ & & Höganäs \\
\hline M-341.33 & $\mathrm{Ni} 16 \mathrm{Cr} 15.5 \mathrm{Mo} 4 \mathrm{~W} 3 \mathrm{Fe}$ & Hastelloy C-276 & Flame Spray Technologies \\
\hline
\end{tabular}




\section{RESULTS}

Based on the measured diameters and force at cohesion failure, cohesion strengths were calculated according to equation (2). Measured diameters, forces and calculated cohesion strength with mean values and standard deviations can be seen in Table 2. Thicknesses of all tested coatings were around 420 microns.

Table 2 Results of the cohesion strength test

\begin{tabular}{|c|c|c|c|c|c|c|c|}
\hline \multirow[t]{2}{*}{$\begin{array}{l}\text { Coating } \\
\text { material }\end{array}$} & \multirow[t]{2}{*}{$\begin{array}{l}\text { Chemical } \\
\text { composition }\end{array}$} & \multirow{2}{*}{$\begin{array}{c}\text { Thickness } \\
\text { of the } \\
\text { coating } \\
(\mu \mathrm{m})\end{array}$} & \multirow{2}{*}{$\begin{array}{l}\text { Area of the } \\
\text { annulus } \\
\left(\mathrm{mm}^{2}\right)\end{array}$} & \multirow{2}{*}{$\begin{array}{l}\text { Force at } \\
\text { cohesion } \\
\text { failure } F_{m} \\
\text { (N) }\end{array}$} & \multicolumn{3}{|c|}{$\begin{array}{c}\text { Calculated cohesion strength } R_{m} \\
(\mathrm{MPa})\end{array}$} \\
\hline & & & & & $\begin{array}{l}\text { Value for } \\
\text { respective } \\
\text { specimen }\end{array}$ & $\begin{array}{l}\text { Mean } \\
\text { value }\end{array}$ & $\begin{array}{l}\text { Standard } \\
\text { deviation }\end{array}$ \\
\hline \multirow{4}{*}{$\begin{array}{l}\text { Woka } \\
3652\end{array}$} & \multirow[t]{4}{*}{ WC $10 \mathrm{Co} 4 \mathrm{Cr}$} & \multirow[t]{4}{*}{$425 \pm 3$} & 80.01 & 27306 & 341.3 & \multirow[t]{4}{*}{308} & \multirow[t]{4}{*}{30} \\
\hline & & & 79.96 & 25226 & 315.5 & & \\
\hline & & & 79.38 & 20628 & 259.9 & & \\
\hline & & & 80.89 & 25359 & 313.5 & & \\
\hline \multirow{4}{*}{$\begin{array}{c}\text { uM- } \\
484.33\end{array}$} & \multirow{4}{*}{$\begin{array}{l}\text { Co } 28.5 \mathrm{Cr} \\
4.5 \mathrm{~W} 1 \mathrm{C} 1 \mathrm{Si} \\
\text { (Stellite 6) }\end{array}$} & \multirow[t]{4}{*}{$420 \pm 8$} & 78.05 & 32685 & 418.8 & \multirow[t]{4}{*}{411} & \multirow[t]{4}{*}{14} \\
\hline & & & 77.17 & 29863 & 387.0 & & \\
\hline & & & 81.25 & 34251 & 421.5 & & \\
\hline & & & 79.97 & 33347 & 417.0 & & \\
\hline \multirow[t]{4}{*}{ M-771.33 } & \multirow{4}{*}{$\begin{array}{c}\mathrm{Ni} 16 \mathrm{Cr} 4 \mathrm{Fe} \\
4.25 \mathrm{Si} 3 \mathrm{~B} \\
0.7 \mathrm{C}\end{array}$} & \multirow[t]{4}{*}{$418 \pm 13$} & 82.86 & 24943 & 301.0 & \multirow[t]{4}{*}{307} & \multirow[t]{4}{*}{7} \\
\hline & & & 77.13 & 22976 & 297.9 & & \\
\hline & & & 76.51 & 24213 & 316.5 & & \\
\hline & & & 77.73 & 24184 & 311.1 & & \\
\hline \multirow{4}{*}{$\begin{array}{l}\text { Amperit } \\
588.074\end{array}$} & \multirow[t]{4}{*}{$\mathrm{Cr} 3 \mathrm{C} 2$ 25NiCr } & \multirow[t]{4}{*}{$413 \pm 8$} & 76.47 & 9963 & 130.3 & \multirow[t]{4}{*}{138} & \multirow[t]{4}{*}{5} \\
\hline & & & 75.88 & 10556 & 139.1 & & \\
\hline & & & 79.30 & 11077 & 139.7 & & \\
\hline & & & 78.72 & 11307 & 143.6 & & \\
\hline \multirow[t]{4}{*}{ M-341.33 } & \multirow{4}{*}{$\begin{array}{c}\mathrm{Ni} 16 \mathrm{Cr} \\
\text { 15.5Mo 4W } \\
\text { 3Fe (Hastelloy } \\
\text { C-276) }\end{array}$} & \multirow[t]{4}{*}{$421 \pm 11$} & 75.39 & 24299 & 322.3 & \multirow[t]{4}{*}{325} & \multirow[t]{4}{*}{7} \\
\hline & & & 80.72 & 25407 & 314.7 & & \\
\hline & & & 79.66 & 26255 & 329.6 & & \\
\hline & & & 80.56 & 26807 & 332.8 & & \\
\hline
\end{tabular}

Table 3 Visualized results of the cohesion strength of tested commercial materials

\begin{tabular}{|c|c|c|c|c|}
\hline \multirow{2}{*}{ Comercial Powder } & \multirow{2}{*}{ Chemical Composition } & \multirow{2}{*}{$\begin{array}{l}\text { Materials } \\
\text { equivalent }\end{array}$} & \multicolumn{2}{|c|}{ Cohesion Strength (MPa) } \\
\hline & & & $\mathbf{R}_{\mathbf{m}}$ & \pm \\
\hline Woka 3652 & WC 10Co 4Cr & & 308 & 30 \\
\hline FST M-484.33 & Co $28.5 \mathrm{Cr} 4.5 \mathrm{~W} 1 \mathrm{C} 1 \mathrm{Si}$ & Stellite 6 & 411 & 14 \\
\hline FST M-771.33 & $\mathrm{Ni} 16 \mathrm{Cr} 4 \mathrm{Fe} 4.25 \mathrm{Si}$ 3B $0.7 \mathrm{C}$ & & 307 & 7 \\
\hline Amperit 588.074 & $\mathrm{Cr}_{3} \mathrm{C}_{2} 25 \mathrm{NiCr}$ & & 138 & 5 \\
\hline FST M-341.33 & $\mathrm{Ni} 16 \mathrm{Cr}$ 15.5Mo 4W 3Fe & Hastelloy C-276 & 325 & 7 \\
\hline
\end{tabular}

In order to achieve as accurate results as possible, great precision has to take place during production of specimen - for machining, diameter measurements and coating deposition. Even with most precisely 
machined specimens, there can always be production inaccuracies leading to development of other stresses types except simple tension. Although it is not expected for those stresses to have significant influence on calculated cohesion strength. Table 3 reviews visualized results of cohesion strength of tested commercial materials.

\section{CONCLUSION}

Non standardized test for coating cohesion strength evaluation was presented. Principle of the test, specimen preparation, coating deposition and calculation of the results were described. Moreover cohesion strengths of five HVOF coatings of commercial powders were evaluated.

Same coating thicknesses around 420 microns were selected for all tested materials. This thickness is slightly above commonly required thickness for selected HVOF coatings, which is mostly between 250 and 400 microns (although with many exceptions depending on the actual industrial use of coated part). With four tested specimen for each material, standard deviations of the results were in order of few percent, with exception of Woka 3652 (WC 10Co4Cr) that exhibited slightly higher standard deviations around $10 \% . \mathrm{Cr}_{3} \mathrm{C}_{2}-25 \mathrm{NiCr}$ proved to have by far the lowest cohesion strength of all 5 tested HVOF coatings with values around $138 \mathrm{MPa}$. Stellite 6 coating showed highest cohesion strength of all tested materials with values around $411 \mathrm{MPa}$.

The adherence and coating cohesion is strongly influenced by the residual stresses [9]. Since the residual stress in the coating depends on the thickness, it can be assumed, that values of cohesion strength will vary with the changing coating thickness $[9,10]$. Therefore more tests performed on different thicknesses of those coatings could provide a deeper insight to the influence of residual stresses on the cohesion of these HVOF coatings.

\section{ACKNOWLEDGEMENTS}

\section{The paper has originated in the framework of the solution of project number SGS-2019-008}

\section{REFERENCES}

[1] Handbook of thermal spray technology. Materials Park, OH: ASM International, 2004. ISBN 0-87170-795-0

[2] SASSATELLI, P., BOLELLI, G., et al. Properties of HVOF-sprayed Stellite-6 coatings. Surface and Coating Technology. 2018, vol. 338, pp. 45-62.

[3] JACOBS, L., HYLAND, M. M., DE BONTE, M. Study of the influence of microstructural properties on the slidingwear behavior of HVOF and HVAF sprayed WC-cermet coatings. Journal of Thermal Spray Technology. 1999, vol. 8, pp. 125-132.

[4] MIGUEL, J.M., GUILEMANY, J.M., VIZCAINO, S. Tribological study of NiCrBSi coating obtained by different processes. Tribology International. 2003, vol. 36, pp. 181-187.

[5] MORIDI, A., HASSANI GANGARAJ, S.M., VEZZU, S., GUAGLIANO, M. Number of Passes and Thickness Effect on Mechanical Characteristics of Cold Spray Coating. Procedia Engineering. 2014, vol. 74, pp. 449-459.

[6] MUŠÁLEK, R., PEJCHAL, V., VILÉMOVÁ, M., MATĚJÍČEK, J. Multiple-Approach Evaluation of WSP Coating Adhesion/Cohesion Strength. Journal of Thermal Spray Technology. 2012, vol. 22, pp. 221-232.

[7] WATANABE, M., BRAUNS, Ch., KOMATSU, M., KURODA, S., GÄRNER, F., KLASSEN, T., KATANODA, H. Effect of nitrogen flow rate on microstructures and mechanical properties of metallic coatings by warm spray deposition. Surface and Coatings Technology. 2013, vol. 232, pp. 587-599.

[8] ISO 6892-1:2019, Metallic materials - Tensile testing - Part 1: Method of test at room temperature.

[9] BANSAL, P., SHIPWAY, P.H., LEEN, S.B. Effect of particle impact on residual stress development in HVOF sprayed coatings. Journal of Thermal Spray Technology. 2006, vol. 15, pp. 570-575.

[10] STOKES, J., LOONEY, L. Residual stress in HVOF thermally sprayed thick deposits. Surface and Coating Technology. 2004, vol. 177-178, pp. 18-23. 